\title{
CLASSE TRABALHADORA, CONFRONTO POLÍTICO E DEMOCRACIA: $O$ CICLO DE GREVES DO ABC PAULISTA E OS DESAFIOS DO SINDICALISMO ATUAL ${ }^{1}$
}

\author{
Marco Aurélio Santana ${ }^{a}$
}

aé professor do Programa de Pós-Graduação em Sociologia e Antropologia e do Departamento de Sociologia do Instituto de Filosofia e Ciências Sociais da Universidade Federal do Rio de Janeiro

(IFCS-UFRJ).Rio de Janeiro, Rio de Janeiro,Brasil.E-mail: <marcosilvasantana@gmail.com>

Orcid: 0000-0002-3181-6964

http://dx.doi.org/10.1590/0102-019065/104

\section{Apresentação}

O ciclo de contestação aberto com a greve dos metalúrgicos de 1978 completa quarenta anos. Ele representou um dos momentos de ouro da história do movimento operário e sindical brasileiro. Um olhar sobre ele, hoje, é de grande valia. Seja pelo evento em si mesmo e sua importância histórica, bem como quando o colocamos em diálogo com o momento atual da política, do mundo do trabalho e do sindicalismo em nosso país. Ainda mais em um contexto em que trabalhadores(as), suas organizações e formas de luta vivem um duro período regressivo em nível global; em que a democracia - mesmo aquela limitada - sofre sérias transformações e restrições que as assemelham cada vez mais com autocracias ou regimes ditatoriais de novo tipo, e em que há um avançado processo de criminalização dos movimentos sociais nos mais variados quadrantes.

\footnotetext{
1 Agradeço à University of California at Berkeley por ter me garantido o acesso à grande parte da literatura referida neste artigo, principalmente via JSTOR. Isso foi possível graças ao Estágio Sênior da Capes, realizado em 2017-2018, naquela instituição.
} 
Quando, em 12 de maio de 1978, os trabalhadores da Scania, no ABC Paulista, cruzaram os braços e pararam as máquinas, produziram um evento cujos impactos foram sentidos em variadas esferas da vida nacional. Ele tinha raízes e se estruturara a partir de vários processos, o que ao mesmo tempo em que o tornava particular, tornava-o parte de uma cadeia de acontecimentos anteriores e posteriores.

Em termos de seu contexto geral, concordamos com Noronha (2009, p. 120) quando assinala que "o ciclo excepcional de greves ocorrido recentemente no Brasil vincula-se às características da transição democrática brasileira, à superação do modelo desenvolvimentista e a um ambiente macroeconômico excepcionalmente instável".

Apesar de deflagradas no mundo do trabalho, e demandando pontos diretamente relativos a essa esfera, as greves de 1978, 1979 e 1980 portavam muito mais do que isso. Inseridas em um contexto ditatorial, ainda em distensão e transicional, 20 as greves atingiam em cheio a lógica de ação do regime para o mundo do trabalho. A política salarial de arrocho, imposta desde os primórdios da ditadura e que sempre teve a oposição dos setores mais combativos do sindicalismo nacional, a um só tempo controlava os salários - tornados vilões do processo inflacionário -, e trazia para dentro do Estado as tensões entre capital e trabalho quanto a esse tema. Ao longo do período ditatorial, uma negociação salarial se transformava em algo politizado na origem, já que deixava de ser uma mera negociação salarial entre capital e trabalho, mas algo que poderia fazer ruir a política econômica do regime. Ainda mais com a presença de uma categoria forte como a dos metalúrgicos.

Além do que, uma negociação salarial não resolvida negocialmente, que pudesse transbordar os rígidos canais e limites estabelecidos para tanto, poderia servir de faísca para um estopim já curto que levaria a classe trabalhadora, sob a pressão do arrocho, de relações de trabalho autoritárias e indignas, da falta de liberdade política etc., a entrar em 
combustão, fazendo incandescer todo o corpo social. Isso deveria ser evitado a todo custo.

Para o patronato, beneficiário da maioria das medidas do regime, o controle salarial, ainda que limitasse possíveis movimentos táticos de escape nas negociações mais difíceis, era fundamental para o processo de acumulação. A falta de liberdade política era essencial para o controle da força de trabalho, articulando organicamente despotismo fabril e despotismo político. As restrições às atividades sindicais e ações coletivas indispensáveis para a manutenção e reprodução de toda essa urdidura. Fácil de entender, daí, não só a retrossustentação entre o regime e o capital, na origem e continuidade do sistema, como também a articulação orgânica entre eles desde o mundo do trabalho. Basta lembrarmos, por exemplo, do sistemático fluxo de informação entre os setores de recursos humanos de grandes empresas e os órgãos de informação e repressão do regime.

Assim, as demandas apresentadas pelos metalúrgicos, seja em termos da questão salarial, das condições de trabalho e da organização por local de trabalho questionavam pilares importantes de sustentação do regime político e do regime fabril. Com seu engajamento e luta, questionavam o autoritarismo do regime e das relações de trabalho. Ainda que não estivesse explícita de imediato nas formulações dos trabalhadores(as), passando a estar no desenrolar do processo, a demanda por democracia econômica, política e social nos parece perpassar todo o ciclo em termos de forma e conteúdo.

Este artigo analisa os movimentos de greve dos metalúrgicos do ABC Paulista, ocorridos nos anos de 1978, 1979 e 1980, e que marcam o início de um longo ciclo de greves 
e contestação que atravessará as décadas de 1980 e 1990². Nesse sentido, buscaremos levar em conta a dinâmica de confrontação constituída a partir das interações entre trabalhadores(as), patronato e Estado.

Ainda que seja dada atenção às práticas dos patrões e do Estado, ênfase central será dada ao movimento da classe trabalhadora. A ideia é apresentar a forma como os(as) trabalhadores(as) participaram dessa dinâmica, percebendo os limites e possibilidades dessa participação. Isso será feito levando-se em conta fatores externos e internos ao referido movimento, tais como o contexto histórico no qual se insere o estabelecimento da confrontação, as formas de ser dos movimentos, bem como as disputas entre posições político-ideológicas atuantes no interior sindicalismo.

Nesse sentido, como indicado por Tilly (1992, p. 114), é preciso sempre atentar para "a necessidade de vincular os processos históricos, econômicos, políticos, ideológicos e aqueles da ação coletiva". Além do que, evitar modelos de análise com "pressuposição baseada claramente em atores já constituídos, no qual a posição política resta mais ou menos estável e fixa" (Tilly, 1992, p. 113). Mais rico, dinâmico e frutífero seria

[a] elaboração de uma concepção mais histórica da evolução das formas de ação coletiva, o aprofundamento do estudo das relações entre a organização da vida cotidiana e a participação nos conflitos e, enfim, a conceituação dos atores como redes sociais cambiantes, contingentes e construídas, sujeitos eles mesmos a processos políticos e ideológicos (Tilly, 1992, p. 113).

\footnotetext{
2 Na verdade, como indicado por Noronha (2009), aqui se inicia um longo ciclo de greves que irá até 1997. Acreditamos que esse trecho inicial do ciclo, principalmente no caso das greves do ABC, em termos de continuidade e inovação, é importante para a compreensão de muito do que ocorreu posteriormente no que toca as dinâmicas da ação coletiva.
} 


\section{Um cenário em reconstrução}

Com a deflagração do golpe de Estado de 1964, o movimento sindical brasileiro foi duramente atingido, assim como as organizações de esquerda que nele atuavam. A prisão de nomes importantes, a desestruturação do trabalho nos sindicatos e nas fábricas desbarataram atividades que levariam bastante tempo para serem recompostas. Ruía, sob a força da repressão, mais de uma década de incansável e profícuo trabalho nos vários níveis organizativos e mobilizatórios.

Em termos do movimento operário, o que restou, como tradicionalmente restava em períodos como esse, foi o trabalho pequeno e silencioso no chão de fábrica. Era preciso recompor forças e somar esforços. Esse trabalho deu frutos relevantes, mantendo, ainda que em fogo brando, o movimento dos(as) trabalhadores(as). Assim, além das valorosas e mais visíveis mobilizações nas greves de Contagem e Osasco, em 1968 (Neves, 1995; Santana, 2001; Weffort, 1972), foram numerosas aquelas paralisações, greves etc. que, embora não chegassem ao grande público, demonstravam a inquietação e insatisfação da classe trabalhadora. Não se pode confundir falta de aparição pública com não existência, falta de agência, inação. Ao longo de todo o período ditatorial a classe trabalhadora não deixou de atuar, de uma forma ou de outra, como sempre, por dentro ou por fora de suas entidades representativas ${ }^{3}$.

Além disso, não se deve desprezar o avanço lento, mas consistente, de setores progressistas no interior da estrutura sindical oficial. Todo esse quadro de atuações, ao longo dos anos 1960 e 1970, ia preparando o terreno para

\footnotetext{
3 As formas de atuação foram muito variadas, tanto no sentido da resistência quanto no sentido do apoio ao regime. Por certo, como em outros períodos, setores da classe trabalhadora defenderam iniciativas de apoio ao regime e práticas negociais diante do patronato. Aqui daremos atenção às dinâmicas relativas à inquietação social, à resistência e à conflitividade desde o mundo do trabalho.
} 
o ressurgimento do movimento dos(as) trabalhadores(as). As greves iniciadas no ABC Paulista em 1978 podem ser vinculadas não só ao movimento de resistência geral da classe trabalhadora brasileira ao regime militar, mas também às iniciativas e aos impactos dessa resistência no próprio $\mathrm{ABC}$ (Martins, 1994). Como assinala Antunes (1988, p. 13), "Maio de 1978 tem suas raízes no cotidiano operário, tecido especialmente nos primeiros anos da década".

Os vínculos da mobilização grevista alcançam também as tentativas do Sindicato dos Metalúrgicos que, já de algum tempo, apesar dos limites impostos, vinha tentando ao menos refrear o arrocho salarial e o aumento da exploração no trabalho. Em 1974, ainda sob a presidência de Paulo Vidal, o sindicato organiza o I Congresso dos Metalúrgicos de São Bernardo do Campo. Esse encontro definirá as orientações futuras do órgão em termos da liberdade e autonomia sindical por uma lei básica do trabalho que contemplasse os seus direitos fundamentais e pela contratação coletiva de trabalho.

É com esse tipo de definição que Luiz Inácio da Silva, o Lula, que já vinha participando da direção da entidade - trazido por seu irmão Frei Chico, militante do Partido Comunista Brasileiro (PCB) -, chega à presidência do sindicato em 1975. De certa forma, os procedimentos em termos de campanhas salariais não se alterariam nos anos seguintes. Apesar de algumas conquistas no varejo, no atacado, era uma relativa mobilização e a validação dos índices oficiais.

O quadro para o ano de 1977 seria o mesmo, com o fator agravante de que as empresas empreenderam elevado número de demissões, o que aumentou fortemente a inquietação e insatisfação nos meios operários. Além disso, um outro elemento importante dará tons mais fortes ao cenário que se repetia, produzindo possibilidades alternativas: a denúncia de que, nos anos de 1973 e 1974, o regime militar 
maquiara os índices de inflação, mascarando o verdadeiro índice do custo de vida (Humphrey, 1980; Rainho, 1980).

Certamente, diante de uma realidade de regime ditatorial, sentido, em termos concretos, pela classe trabalhadora cotidianamente, circulavam informações sobre esse tipo de prática, que depois tiveram início de materialidade em indicações do Departamento Intersindical de Estatística e Estudos Socioeconômicos (Dieese). Quando apareceu referendada em um documento do Banco Mundial, o que era "especulação" tornou-se realidade.

Lembremos que já no funcionamento "normal” do cálculo inflacionário, a classe trabalhadora tinha seus rendimentos achatados. Com um cálculo baseado em números "alterados", essa perda ainda era maior. Isso levou os(as) trabalhadores(as) a serem penalizados em 34,1\%. O sindicato começou uma campanha pela reposição salarial em busca daquilo que lhes havia sido, de forma espúria, retirado. Ainda que experimentasse e tivesse de enfrentar o pouco ou nenhum interesse dos patrões e do governo no sentido da reposição, essa campanha será muito importante no quadro das mobilizações futuras.

Concordamos com Rodrigues (1997, p. 19) quando busca ampliar o escopo da análise sobre ação sindical para além da esfera da produção, articulando-a a outras instituições fora dessa esfera. Ele assinala a importância da luta pela democracia - agregando-a a outros fatores, que conformaram linhas de entendimento, como a superexploração do trabalho (Antunes, 1988; Humphrey, 1980), a resistência operária (Maroni, 1982) e a defesa da dignidade (Abramo, 1999) - como uma das componentes indispensáveis para o entendimento desse ascenso mobilizatório do período. Em sua visão, ele teria se dado

como expressão de uma luta mais geral por direitos de cidadania no interior da sociedade. Quer dizer, ainda que a 
questão imediatamente visível desse movimento tenha sido a luta pela reposição salarial no segundo semestre de 1977, em decorrência da manipulação dos índices da inflação de 1973, o fim último da luta sindical era o direito à cidadania. Essas demandas perpassavam o cotidiano fabril, o bairro, a questão da moradia, melhores condições de vida e trabalho, melhores salários, bem como representavam a afirmação de uma classe trabalhadora que já não aceitava uma cidadania limitada. Nesse sentido, eram atores que prenunciavam, com seu movimento, a necessidade de uma presença mais marcante na vida do país, tanto social quanto politicamente.

A busca do significado desses movimentos a partir da articulação das lutas por direitos sociais e direitos políticos, que os teria transformado em atores centrais e protagonistas na luta pela democracia, esteve presente também na análise de Moisés (1982). Nessa linha, Sader indica como esses movimentos vão tecer as ligações entre a vida cotidiana e a política, concebida sob formas e conteúdos distintos das vigentes. Segundo ele, os movimentos

[a]pontaram para uma nova concepção da política, a partir da intervenção direta dos interessados. Colocaram a reivindicação da democracia referida às esferas da vida social, em que a população trabalhadora está diretamente implicada: nas fábricas, nos sindicatos, nos serviços públicos e nas administrações dos bairros. (Sader, 1988, p. 313)

\section{A greve de 1978: raio saído de um céu azul?}

A campanha salarial de $1978^{4}$ termina, repetitivamente, como as anteriores, ou seja, homologando-se os índices oficiais estabelecidos pelo regime. Porém, o sindicato tinha

\footnotetext{
4 Para uma análise mais densa e aprofundada de todo esse processo ver Antunes (1988) e Abramo (1999).
} 
como estratégia desmascarar todo o processo. É por isso que o sindicato se recusa à negociação tutelada pela Justiça do Trabalho, abrindo mão de sua participação no dissídio. Com isso, rompe com a Federação dos Metalúrgicos de São Paulo, que segue em seu ritual anual de negociação, e busca a negociação em separado, mas não inclui índice de aumento salarial na pauta que apresenta. Como assinala Lula (Cadernos do Presente, 1978, p. 73), buscou-se

mostrar ao trabalhador que pouco adiantava ele participar das assembleias do sindicato em termos de salários; de pouco adianta virem vinte mil trabalhadores numa assembleia, porque o decreto do reajuste de salário é dado pelo Presidente da República, e que a participação nas assembleias teria pouca influência na determinação do índice decretado pelo governo.

A política do sindicato, então, era tornar explícita a falácia de participação gerada pelo governo e deixar um vazio em termos da parte referente à representação de trabalhadores(as). A performance da cadeira vazia, durante o que seria o processo de negociação, produziu uma mudança interessante no repertório de ação do sindicato. Conforme Tilly (2008, p. 4), as performances têm papel importante no confronto político, à medida que ele mesmo seria

um produto de performances aprendidas e historicamente situadas. Em dado tempo e espaço, as pessoas aprendem um número limitado de performances pelas quais expressam suas demandas. Então, na maioria das vezes, se mantêm vinculadas a estas performances quando chega o momento de fazer demandas. Performances de confronto mudam incrementalmente como resultado de experiências acumuladas e constrangimentos externos. 
A ausência do sindicato durante o que seria o processo de negociação salarial gerou perturbação na lógica de ação dos representantes do Ministério do Trabalho e da patronal, gerando preocupação com a quebra de um determinado ritual e com o que poderia advir daí. O jogo repetitivo passava a ser jogado com alguma alteração. Na visão de Tilly (2008, pp. 10-11),

Duas performances de confronto não se espelham perfeitamente. De fato, elas perderiam alguns de seus efeitos se operassem com a precisão de exercícios militares. Os participantes improvisam constantemente em duas direções diferentes: imaginando como moldar as rotinas disponíveis para expressar suas demandas e responder às reações daqueles a quem direcionam suas demandas. [...] Neste processo, eles introduzem pequenas inovações nas formas estabelecidas.

O sindicato que, ao longo da campanha de reposição que precedeu a campanha salarial, já vinha batendo na tecla do "roubo" efetuado pelo governo, preparava o caminho para uma desilusão ainda maior ao fim dessa campanha, já que interpelava os(as) trabalhadores(as) apresentando elementos que desvelavam a "farsa" da negociação salarial.

A química produzida pela articulação entre a insatisfação operária e o trabalho desenvolvido pelo sindicato, bem como com aquele de grupos políticos no interior das fábricas, rapidamente trará seus efeitos. Em fins de março, os(as) trabalhadores(as) da Mercedes-Benz já haviam paralisado o trabalho por não terem recebido o aumento que a empresa costumava conceder no período. $\mathrm{O}$ desenvolvimento da paralisação em vários setores da fábrica levou à demissão de 17 operários, fazendo o movimento refluir.

A própria postura da empresa posteriormente indicava certa alteração nos padrões de negociação. $O$ 
endurecimento era sensível. Segundo o relato de um militante sindical, referido por Antunes (1988, p. 19), até aquele momento, o padrão era o de que "os conflitos eram resolvidos lá dentro das fábricas. Conversavam, chegavam num acordo e tal. Bem mais aí o Lula foi lá conversar com o cara da Mercedes, um gerente [que] mandou o Lula se danar".

Em 12 de maio de 1978, os(as) trabalhadores(as) da Scania entraram em greve. Surpreendendo a muitos. O depoimento de um militante sindical assinala que a

greve nasceu de uma decisão espontânea do pessoal do diurno da ferramentaria. O pessoal do noturno estava saindo, quando o turno do dia entrou e não ligou as máquinas. Ninguém começou a trabalhar. Não se ouvia o menor barulho na fábrica. (Antunes, 1988, p. 20)

O movimento se estabeleceu por quatro dias, findos os quais a diretoria do sindicato, chamada para representar os(as) trabalhadores(as), arranca um "acordo de boca" da direção da empresa, acordo que, depois pressionada pelos outros setores da indústria automobilística, a Scania não cumpriu, trocando os $20 \%$ das reivindicações por parcos $6,5 \%$. Nova mobilização é tentada, mas, mediante as práticas repressivas da empresa, não se efetivou.

Nesse início de ciclo, pode-se perceber que as práticas repressivas continuavam servindo como limitador das ações operárias, servindo como um obturador da estrutura de oportunidades. O medo, real, rondava as cabeças dos(as) trabalhadores(as) e lideranças, tanto em termos de possíveis represálias do patronato quanto da ditadura.

Olhando a ação da patronal, em um tipo de dinâmica que se repetiria em outros momentos do ciclo, esse processo sinaliza com questões importantes. Independentemente se era apenas um movimento tático da empresa, que já sabia que não cumpriria o acordo, interessante notar como a 
greve abre uma fissura no setor patronal e em suas práticas. Ainda que tenha aceitado o acordo, e que até pudesse cumpri-lo, tendo condições para isso, a empresa teve de recuar e cerrar fileiras novamente com seu setor. Aceitando e cumprindo o acordo, a empresa sinalizaria para a possibilidade do setor de conceder aumento maior do que o índice do governo, o que, a um só tempo, abriria a porteira para outras mobilizações em outras fábricas e no setor como um todo, bem como abriria um flanco de demolição da política econômica da ditadura.

Mas, as mobilizações por fábrica já se alastravam pelo ABC Paulista. No dia 15 de maio, para a Ford e, no dia 16, a Volkswagen. Apesar da posição do Tribunal Regional do Trabalho (TRT) de considerar as greves ilegais, isso foi o início de uma onda mobilizatória que alcançou grandes, médias e pequenas empresas, desenvolvendo tipos variados de greve e com duração diversa, acabando por atingir outros municípios, como Osasco e São Paulo. A mobilização chega também a outros setores da economia (Humphrey, 1980).

Um ciclo de contestação e protesto se inaugura, abrindo todo um horizonte de possibilidades. Segundo Tarrow (1993, p. 285),

Embora ondas de protestos não tenham uma frequência regular ou se estendam uniformemente para populações inteiras, um número de elementos têm caracterizado estas ondas na história recente. Eles incluem aumento dos conflitos, ampla extensão setorial e territorial, o aparecimento de novas organizações dos movimentos sociais e o empoderamento das antigas, a criação de novos eixos vertebradores de sentido, e a invenção de novas formas de ação coletiva ${ }^{5}$.

\footnotetext{
${ }^{5}$ Além de Tarrow (1993), sobre ciclos de protesto, ver também, entre outros, Snow e Benford (1992).
} 
Sem dúvida esse movimento significou o passo fundamental para a retomada do movimento operário e sindical brasileiro em termos da cena política mais geral, no que se abriria como a quadra final do regime militar. Todo um conjunto de articulações entre setores civis e militares vinha sendo feito sem que a classe trabalhadora dele participasse. Agora, os(as) trabalhadores(as) se estabeleciam no cenário político nacional como uma força não mais silenciável e nem negligenciável.

Conforme assinalou, ainda no calor da hora, Munakata (1980, p. 61)

$\mathrm{O}$ acontecimento político mais importante do primeiro semestre deste ano [...] Foi, na realidade, a irrupção do movimento grevista que, iniciado na região do $\mathrm{ABC}(\mathrm{SP})$, rapidamente se alastrou pelos grandes centros industriais e urbanos do estado, envolvendo centenas de milhares de trabalhadores [...] fato político mais importante, sim. Embora a análise da dimensão e das consequências precisas deste surpreendente movimento esteja ainda por fazer [...], não se pode negar que o movimento fez emergir à tona da pantanosa cena política brasileira um novo fator: exatamente a presença dos trabalhadores, o que, aliás, já foi amplamente constatado.

Em uma entrevista dada à revista Visão, em 3 de abril de 1978, antes da greve, Lula dizia que "o caminho ficou muito tempo fechado, o mato cresceu e está impedindo os trilhos. Agora, estamos apenas cortando o mato, desobstruindo a linha” (SILVA, 1981, p. 49). O fato é que, de uma só vez, os(as) trabalhadores(as) colocavam em xeque tanto a política salarial quanto a política antigreve do governo, chocando-se com o conjunto da política de arrocho empreendida de longa data pela ditadura militar. Um fato de extrema importância nesse processo foi terem ampliado os horizontes de 
possibilidades. Com a sinalização dada por um setor forte e central como os metalúrgicos, estabelecia-se um novo patamar de mobilização social nos mais diversos níveis.

Cabe dizer que no interior do movimento existiam variadas posições com relação às formas de organização e mobilização. A posição do PCB, ator político importante, que se esforçava para manter seu lugar histórico de "representante da classe operária" perante os setores emergentes acerca dessa greve e de outros movimentos que se espalham pelo país, desdobra-se no plano sindical e no plano político geral. No plano sindical, a perspectiva comunista era de uma análise positiva da greve, devendo evitar, contudo, o "triunfalismo", evitando-se cair no que seriam "erros do passado".

Acerca do plano político mais geral, a política comunista pode ser aferida na Declaração do Comitê Central do PCB sobre o movimento sindical, publicada no Voz Operária $\mathrm{n}^{\mathrm{o}}$ 152, de novembro de 1978 (Carone, 1982). Nesse documento, o partido avalia que o regime ia apresentando crescente debilitamento explicitado pelo ascenso do movimento popular em busca de seus direitos. Assim, esses movimentos e as lutas operárias teriam aberto uma primeira brecha em uma área das mais sensíveis do sistema, isto é, sua política salarial antioperária, base da política econômica do regime.

Do ponto de vista da análise do partido, o avanço do movimento operário teria significado "uma importante mudança na situação política nacional, dando novo conteúdo às lutas e exigências do campo democrático", já que "ao reivindicar liberdades políticas, juntamente com seus direitos econômicos e sociais" lançou a luta pela democracia em outro patamar, abrindo caminho "que conduza a transformações realmente profundas na vida política e social brasileira" (Carone, 1982. p. 371).

Seguindo as indicações mais amplas do PCB, o documento vai realçar a preocupação das articulações necessárias entre as lutas operárias e as lutas mais gerais pela 
democracia, que seria uma condição primordial para a efetiva participação e influência do operariado na vida política do país. O PCB indicava que não se deveria abrir mão de outros objetivos, tais como mudar a estrutura sindical para libertar as entidades sindicais da tutela do Ministério do Trabalho, assegurar a livre organização sindical de trabalhadores(as) a partir dos locais de trabalho, até a conquista de uma Central Única dos Trabalhadores (CUT).

Podemos ressaltar, contudo, que a parte referente à luta dos(as) trabalhadores(as) em termos das lutas gerais pela democracia não se dava de forma tão direta quanto o partido acreditava, ou queria acreditar. Isso fica evidente nas posições esposadas por muitos desses "novos atores" acerca dos vínculos com outros movimentos, o que também irritava aqueles que gostariam de ver uma integração mais efetiva ${ }^{6}$.

A greve de 1978 apresentou à cena pública a "rebeldia do trabalho" em sua "luta pela dignidade" e cidadania plena. Ela não foi propriamente um raio saído de um céu azul. Costuma-se pensar nesse tipo de movimento, conforme a fala de um militante sindical citado anteriormente, pela via da espontaneidade. Nesse caso, ainda mais, já que a greve partiu do chão de fábrica, tendo o sindicato sido chamado posteriormente. Essa era a ideia que rondou também o entendimento das greves de Contagem e Osasco (Weffort, 1972), em uma chave de entendimento ainda em voga naquele período. Contudo, assim como as greves de nosso 1968 operário, a greve de 1978 pode ser entendida a partir da composição de um conjunto de forças, atores, organizações, campanhas, histórias de vida e experiências que serviram de base processual para o deflagrar daquele

${ }^{6}$ Ao despontar como líder sindical de expressão nacional após a greve de 1978, Lula, em suas entrevistas iniciais, esposava posições que marcavam a separação entre o movimento sindical e outros movimentos sociais. Além disso, em plena luta pela anistia, marcava sempre que a verdadeira anistia deveria ser dada à classe trabalhadora. Ficou famoso seu debate com Terezinha Zerbini acerca disso. Ver Silva (1981). 
acontecimento que, desse ponto de vista, teria sido mais que um ato de combustão espontânea.

Por um conjunto de fatores, os próprios participantes dos movimentos sociais costumam relatá-lo como uma ocorrência "espontânea", como algo impulsivo, não planejado, imediato, vindo de baixo ${ }^{7}$. O estudo de Polletta (2006) sobre a construção de narrativas e como elas são contadas nos e pelos movimentos sociais assinala a importância das conexões sociais, dos esforços organizativos que precedem, acompanham e persistem, ou não, em todas as ações coletivas. De todo modo, um dado interessante nessa narrativa do espontâneo é que, segundo Polletta (2006, p. 33), em sua análise sobre os sit-ins: "quando os estudantes descrevem os sit-ins como "espontâneos", e como "explodindo", "transbordando" e "como uma febre”, eles capturam o indefinível momento quando um grupo de indivíduos separados se torna um ator coletivo".

Com os caminhos interditados por uma década após as greves de Contagem e Osasco, a classe trabalhadora brasileira, a partir da greve de 1978, recuperava seus espaços de participação aberta e pública, com repercussões importantes por todo o corpo social e político nacional. A construção desse ator coletivo, que assumirá a identidade de "novo sindicalismo", rapidamente vai se associar à construção de ator político. Esse processo porta um conjunto de dimensões,

\footnotetext{
7 Polletta (2006) chama atenção para o fato de que dada a herança de perseguição ao comunismo nos Estados Unidos, um dos desafios mais espinhosos para os ativistas é não serem acusados de comunistas ou de terem seus movimentos controlados "de fora", o que é o mesmo de ser controlado por comunistas. Assim, precisam, estrategicamente, indicar que seus movimentos cresceram das bases locais, repentinos e não planejados. Vale lembrar, em semelhança ao caso brasileiro, que nesse período ditatorial havia todo um risco em ser identificado com os comunistas ou com a esquerda. Ficou famosa a tirada de Lula quando perguntado se era socialista respondendo "sou torneiro mecânico".

8 Movimento deflagrado a partir da ação de quatro estudantes universitários negros, na Carolina do Norte, que, em $1^{\circ}$ de fevereiro de 1960 , sentaram-se na parte então reservada para brancos demandando serem atendidos, caso não o fossem ficariam ali até que a loja fechasse. Eles voltaram em dias sucessivos, agora com o apoio de outros estudantes. O movimento logo se espalhou para várias outras cidades do país.
} 
inclusive a discursiva. Ao analisar o mesmo período, Sader (1988, p. 60) usa como enquadramento a ideia de que

todo discurso é obrigado a lançar mão de um sistema de referências compartilhado pelo que fala e seus ouvintes. Constitui-se um novo sujeito político quando emerge uma matriz discursiva capaz de reordenar os enunciados, nomear aspirações difusas ou articulá-las de outro modo, logrando que indivíduos se reconheçam nesses significados.

Ao longo do ano de 1978, em meio ao processo de ascenso da classe trabalhadora e de suas organizações, começa a se desenvolver a ideia da criação de um partido que emergisse da classe trabalhadora e que lhe servisse de representação política.

Lula, já em julho de 1978, em uma entrevista ao Diário do Grande ABC (SILVA, 1981, p. 123), indicava os limites de participação política da classe trabalhadora. Segundo ele, devido às restrições do "jogo", os partidos então existentes, criados e com "regras que não foram feitas pela classe trabalhadora, dificilmente a classe trabalhadora conseguirá participar deles”. Para Lula, contudo, "o trabalhador já tem condições de começar a se preparar para a criação de um partido político.[...]. A sigla, naturalmente deve ser discutida com a classe trabalhadora".

Apesar de, sucessivamente, Lula demonstrar sua desconfiança na capacidade dos partidos legalmente existentes, o Movimento Democrático Brasileiro (MDB) e a Aliança Renovadora Nacional (Arena), frutos do bipartidarismo imposto pelo regime militar, de representarem os interesses da classe trabalhadora, ele mesmo indicava que, apesar disso, a classe deveria não ver partidos, mas nomes. Como ele dizia à revista Visão, em abril de 1978: 
não vejo também o MDB como salvação de nada. É um partido como a Arena. Tem gente boa no MDB, assim como há gente boa na Arena. O sindicato deve participar somente daquilo que é melhor para a classe, seja qual partido for. (SILVA, 1981, p. 48) ${ }^{9}$

Os "novos atores" emergentes duvidavam das iniciativas dos partidos então legalmente existentes, e se colocavam na perspectiva da criação de um novo partido. O Partido dos Trabalhadores (PT) dava seus primeiros passos saindo dos projetos para se tornar realidade ${ }^{10}$.

\section{A greve (geral) de 1979}

$\mathrm{O}$ ano de 1979 veria se desenvolver e aumentar a participação da classe trabalhadora no cenário político nacional. Desde a greve de 1978, o movimento se desdobrara, espalhara e atingira diversas categorias e estados pelo país, entre os quais centros importantes como Rio de Janeiro, Minas Gerais e Rio Grande do Sul. Mas é novamente no ABC Paulista, entre os metalúrgicos, que a mobilização vai transcender os limites impostos e colocar a luta dos(as) trabalhadores(as) e a luta pela democratização do país em outro patamar.

A campanha salarial dos metalúrgicos do ABC trazia elementos novos em termos de suas demandas. Além do reajuste salarial, era reivindicada também a garantia de emprego e a implantação de delegados sindicais no

\footnotetext{
9 Já em setembro de 1978, Lula dizia ao jornal Folha de S.Paulo: "acho que existem pouquíssimos representantes dos trabalhadores na Câmara e no Senado. Podemos contar, quando muito, meia dúzia de parlamentares que são trabalhadores, vieram do nosso meio. O MDB, é verdade, tem se mostrado bem mais acessível às reivindicações da classe trabalhadora e não poderia ser de outra forma, sendo o partido da oposição. Mas eu acho que, no bipartidarismo, é mais importante escolher o homem que se afina mais com os programas da classe trabalhadora" (SILVA, 1981, p. 79).

10 Não sendo possível discutir todo esse processo de criação do PT e seus impactos nos meios sindicais, políticos e de esquerda no escopo deste artigo, remeto os leitores a, entre outros, Santana (2001, 2007, 2012).
} 
interior das empresas. Diante da preparação da mobilização pelos(as) trabalhadores(as), os empresários começam a solicitar medidas punitivas por parte do governo em caso de greve. Essa mesma classe empresarial, acostumada à intransigência e ao acobertamento por parte do Estado, dava sinais de que viria mais preparada para o embate.

Esse tipo de preparação fica explicitado, entre outros, no documento circulado entre seus filiados pela Federação das Indústrias do estado de São Paulo (Fiesp) (Sader, 1988). Nele, a entidade deixa claras suas intenções de fornecer orientações às suas bases, controlar possíveis comportamentos de possíveis divisões internas - "Não pagar em nenhuma hipótese horas paradas e não estabelecer acordos e compensações" (Sader, 1988, p. 303) - e, mais ainda, de tentar "de todas as formas colocar os grevistas na via pública" (Sader, 1988, p. 303) para arrolar o poder público no processo.

Além disso, a Federação apresenta orientações no sentido de ataques diretos às possíveis movimentações dos(as) trabalhadores(as). Nesse sentido, práticas como "Suspender por um ou dois dias (disciplinarmente) aqueles que entrarem na fábrica sob condições de trabalhar e não cumprir o prometido" (Sader, 1988, p. 303), bem como "dispensar um certo número de pessoas por justa causa, após, junto com o responsável pela área paralisada, pedir ao trabalhador que execute uma determinada tarefa (a negativa caracterizará um ato de insubordinação)" (Sader, 1988, p. 303), tinham destaque. Tudo isso para produzir uma situação de "insegurança no pessoal" - trabalhadores(as) e sindicato - que gerasse a "volta ao trabalho".

Desse ponto de vista, e já com a greve de 1978 incorporada ao campo de possibilidades, pode-se perceber que os contendores em confronto virão de forma mais organizada e planejada para a arena do conflito. O elemento surpresa não estaria mais na deflagração ou não de movimentos grevistas, mas em possíveis pontos dentro do processo de 
negociação e mobilização. Após dez anos sem grandes mobilizações, essa perspectiva era considerada fraca. Agora, após a greve do ano anterior, era forte e muito presente. Todos se preparavam como nunca para essa campanha salarial.

A partir do dia 12 de março de 1979, em assembleia convocada pelo sindicato, mais de 50 mil trabalhadores(as) metalúrgicos(as) decidiram entrar em greve e paralisar o trabalho. Essa paralisação se deu em pleno processo de passagem do poder militar do general Ernesto Geisel para o general João Figueiredo. Por óbvio, as estruturas ditatoriais não ficariam passivas. No dia 13 de março, grandes empresas, como a Ford e a Volks, já amanheceram paralisadas, dando claro sinal do que se poderia esperar daquele movimento.

A primeira assembleia durante a greve foi realizada debaixo da chuva fina que caía naquela tarde do dia 13, no Estádio de Vila Euclides. Por força da improvisação, não havia palanque nem sistema de som. O presidente do sindicato, Luís Inácio Lula da Silva, falou para mais de 60 mil trabalhadores de cima de uma mesa, e suas palavras eram sucessivamente repetidas e passadas para trás. (Greve..., 1979).

No segundo dia de paralisação, a greve já se estendera ao interior do estado e era considerada ilegal pelo TRT. Apesar disso, os(as) trabalhadores(as) continuam com sua disposição de luta. Se o movimento de 1978 foi marcado pela paralisação parcial por empresas, esse de 1979 era um movimento de greve geral da categoria. Em seu quarto dia, a greve já conta com cerca de 170 mil trabalhadores(as) paralisados(as) em todo o $\mathrm{ABC}$, demonstrando todo o fôlego do movimento. Já contando dez dias de paralisação, o Ministério do Trabalho tenta intervir no processo, apresentando uma proposta de conciliação que indicava a criação de uma comissão tripartite para estudar o reajuste em um prazo de 45 dias, a não demissão dos grevistas e o 
pagamento das horas paradas a serem descontadas mais tarde com parcelamento.

Tal proposta foi repudiada por 80 mil metalúrgicos de São Bernardo, no Estádio de Vila Euclides, 30 mil de Santo André e 6 mil de São Caetano, em suas respectivas assembleias. A resposta do Ministério do Trabalho não se fez esperar. No dia 23 de março, foi decretada a intervenção nos sindicatos. Os momentos que se seguiram à intervenção foram marcados por muita tensão. Por diversas vezes, a massa de trabalhadores(as) quase partiu para enfrentamento com as forças policiais em praça pública. A intervenção saiu pela culatra à medida que o governo, afastando a verdadeira liderança operária, e sem conseguir emplacar os interventores como interlocutores de nada, ficou sem qualquer possibilidade de diálogo efetivo e produtivo com os possíveis canais que se conectavam com o movimento da classe. Assim, viu-se forçado a abrir interlocução com estruturas criadas para a manutenção da greve, que realmente representavam os(as) trabalhadores(as), como por exemplo, o Fundo de Greve ${ }^{11}$.

Com seus espaços fechados, os(as) trabalhadores(as) passam a se utilizar da Igreja Matriz para os encontros da liderança sindical e da comissão de salários. Segundo Antunes (1988, p. 48), “Acentuou-se, a partir daí, o papel marcante da Igreja - particularmente da Pastoral Operária do ABC, dirigida por D. Cláudio Hummes - no apoio material e solidário aos operários grevistas".

O fato é que a intervenção na entidade pelo governo, ao mesmo tempo que serviu de elemento radicalizador da massa, em vez de pacificá-la como era a estratégia do poder,

${ }^{11}$ Conforme indicado no sítio ABC de luta! Memória dos Metalúrgicos do ABC (Criação..., 1979), "Sob intervenção durante a greve de 1979 e com a clara concepção de que o sindicato não é sua máquina, nem o prédio onde atua, a diretoria organizou o Fundo de Greve, inicialmente, nos porões do Sindicato e, depois, na Igreja da Matriz de São Bernardo. Em pouco tempo, o Fundo de Greve aglutinou trabalhadores não apenas para a organização da coleta e distribuição de alimentos no caso de uma greve, mas como um núcleo de discussão política nos momentos de intervenção". 
serviu também para deixar o movimento acéfalo. Embora Lula tenha dito que, em caso de intervenção, a comissão de salários assumiria o papel da direção, esse não foi um processo tranquilo e realizável enquanto tal. Por dois dias, em meio a um forte crescimento da temperatura política, o movimento seguiu sem muita coordenação. Após conversa e pressões de líderes sindicais (Arnaldo Gonçalves, presidente do Sindicato dos Metalúrgicos de Santos e membro do PCB, por exemplo) e personagens públicas (Lélia Abramo, atriz, por exemplo), Lula e a direção resolvem reassumir a greve.

$\mathrm{O}$ movimento já apresentava certo sinal de refluxo. Na terça-feira, dia 27 de março, em assembleia, seguindo avaliação do comando de greve, os(as) trabalhadores(as) aceitam um acordo com o patronato, que estabelecia o prazo de 45 dias para novas negociações em busca do índice satisfatório, findo o qual os metalúrgicos entrariam em greve mais uma vez. Ainda que com alguma resistência na assembleia, a proposta foi aceita majoritariamente.

Com o retorno a certa normalização, o sindicato passava à retomada de suas atividades. Segundo Lula, era uma verdadeira operação de guerra na qual os militantes sindicais intensificaram seu trabalho de porta de fábrica e de panfletagem. A lógica intransigente da ação patronal só será quebrada quando, no $1^{\circ}$ de maio, 130 mil trabalhadores(as) reiteram sua posição e indicam a deflagração de nova greve como fato iminente. No dia 12 de maio, o sindicato celebra um acordo com a Fiesp, que será referendado no dia 13 de maio por uma assembleia de trabalhadores(as). Segundo Antunes (1988, p. 53), evidenciava-se que

apesar de esse acordo ser mais vantajoso do que aquele assinado pela Federação, era ainda bastante insatisfatório. Sua aprovação pela assembleia geral metalúrgica deveu-se, de um lado, à dificuldade de obtenção de algo mais 
favorável e, de outro, à priorização que passou a ser dada no sentido da recuperação do Sindicato pelos operários.

Conforme assinala Humphrey (1980, p. 27):

A greve não foi um êxito total para os operários. Os três sindicatos se viram muito próximos de uma séria derrota e forçados a aceitar uma solução de compromisso [...]. A greve foi, entretanto, uma séria derrota para os patrões e o Estado. Em vez de pôr fim à greve com a intervenção [...] o Estado se viu forçado a reconhecer os líderes depostos como legítimos representantes dos operários.

Antes do fim da greve, setores de esquerda começam a análise acerca dos limites e possibilidades da mobilização dos(as) trabalhadores(as). No caso do PCB, a postura era: a luta contra o arrocho, pilar da política econômica da ditadura militar, teria centralidade. $\mathrm{O}$ restante, sem inserção na massa, deveria vir com a luta e a consolidação da democratização. Aqui, fica indicado um dos pontos que, em breve, distanciarão grandemente os comunistas desses "novos atores" surgidos no início do ciclo. Esse tipo de etapismo propugnado pelo PCB, empurrava-o contra certas demandas e propostas em debate em um movimento sindical em clara espiral de ascensão e radicalização.

De todo modo, os comunistas não deixarão de identificar as novidades trazidas pelo movimento grevista. O Voz Operária no 157, de abril de 1979 (Carone, 1982), assinala, em meio à "trégua" estabelecida no meio da greve, certas posições dentro do partido, via entrevista com "especialistas" no ramo: Hercules Corrêa e Luiz Tenório da Silva. Ambos, apesar de apontarem limitações no movimento, realçarão as novidades trazidas pela greve. Corrêa (Carone, 1982, p. 386) assinala que

assembleias de 80, 70 mil trabalhadores, isso é novo no Brasil. Novo inclusive para a Europa, que não conhece esse 
tipo de assembleia sindical. [...]. A maior assembleia que eu vi no passado foi uma assembleia de 50 mil no estádio da Mooca, mas que era de várias categorias.

Tenório (Carone, 1982, p. 386) acrescenta que

O fato da greve ter-se dado enquanto um general estava arrumando os papéis, fechando a mala, limpando as gavetas para sair, e o outro pondo a gravata para entrar, eu acho que foi uma tática e revelou muita sensibilidade. Acho que não foi casual.

De todo modo, pode-se sentir que sutilmente os comunistas vão mudando o tom acerca das greves e de seus líderes. Se em 1978 o tom era de muito mais apoio e percepção de possibilidades, agora já se sentem críticas a determinadas posturas e o receio de que as possibilidades fossem de resultados negativos, tanto para os(as) trabalhadores(as) como para a sociedade em sua busca por democratização.

Esse tipo de posição do partido se acirrará em movimentos futuros, na medida em que ele tinha ligação, também, com a consolidação de um bloco alternativo às posturas do PCB e que ia tornando realidade a construção do PT. Ao longo de 1979, o movimento pró-PT se espalhou por todo o país. Como bem indicou Rodrigues (1991, p. 27), a "formação do $\mathrm{PT}$ viria acentuar as divergências já existentes no interior do sindicalismo brasileiro. Os comunistas [...] não poderiam ver com simpatia o surgimento de um outro partido que viesse disputar com os PCs o controle do movimento trabalhista".

$\mathrm{O}$ fato é que a greve geral dos metalúrgicos do $\mathrm{ABC}$ abriu as porteiras para outras formas de mobilização, seja em solidariedade à paralisação dos metalúrgicos, seja em busca de reivindicações particulares. Como havia feito no ABC, o ministro do Trabalho, Murilo Macedo, proferiu duros golpes nas entidades sindicais mais combativas, seguindo-se uma 
onda de intervenções que intentava debelar o ímpeto das mobilizações. Nessa lista estariam, por exemplo, o Sindicato dos Bancários de Porto Alegre, dirigido por Olívio Dutra, e o Sindicato dos Petroleiros de Campinas e Paulínia, dirigido por Jacó Bittar. Sindicatos e lideranças que, entre outros, estarão à frente desse ciclo de contestação e das novas possibilidades abertas em termos de organização da classe trabalhadora, tanto no nível sindical quanto no político.

Mesmo que linhas diferenciadas já fossem se concretizando no movimento sindical há algum tempo, é nesse período que começam a se consolidar identificações, formando blocos de posições que definirão o quadro do movimento dos(as) trabalhadores(as) brasileiros(as) na entrada e ao longo da nova década que se inicia.

\section{A greve de 1980: um ABC de lutas}

Como já ocorrera nos anos anteriores, os metalúrgicos do ABC Paulista iniciavam nova mobilização em campanha salarial que resultará em uma greve que atravessará os meses de abril e maio de 1980. Aos percentuais de aumento (reajuste salarial com base no Índice Nacional de Preços ao Consumidor (INPC), mais $15 \%$ a título de produtividade), integrar-se-iam outras reivindicações como: a garantia no emprego e do salário profissional, a conquista do delegado sindical, a redução da jornada de trabalho para 40 horas, sem redução salarial e o controle das chefias pelos trabalhadores.

Para termos uma ideia ampliada das práticas organizativas e mobilizatórias empreendidas pelos(as) trabalhadores(as) no que tange aos preparativos para mais uma campanha salarial, vale assinalar que

[a] campanha salarial de 1980 teve uma mobilização intensa, através de reuniões com militantes e trabalho de porta de fábrica. O material de propaganda foi inovado, enriquecido, diversificado e sua distribuição aumentada. O Suplemento 
da Tribuna Metalúrgica, que havia sido criado após a greve de 1979, chega a atingir a tiragem de 40 mil exemplares, penetrando clandestinamente no interior das fábricas. Os bairros são envolvidos na campanha e o apoio de entidades e instituições, como a Igreja Católica, foi um fator importante no processo de mobilização. A campanha é aperfeiçoada através da atuação da Diretoria, Comissão de Mobilização e criação de um "grupo especial", incumbido de continuar coordenando o movimento na hipótese da prisão dos diretores. O trabalho de base sistematiza-se. As empresas situadas na base territorial do Sindicato são pesquisadas e distribuídas em áreas, com diretores responsáveis pelo trabalho político em cada uma delas. (Campanhas..., 1980)

Como dizia o lema do sindicato, "tá chegando a hora da onça beber água”. Mas se os trabalhadores(as) iam buscando se apetrechar para os embates vindouros, incorporando e inovando a experiência das duas greves anteriores, o patronato, o regime militar e seus representantes também não ficarão parados e lançarão mão de variados dispositivos no sentido de impedir a movimentação de trabalhadores(as) e, caso isso não fosse possível, debelar a mobilização o mais rápido possível. Como bem indica Antunes (1988, p. 64):

Era o início da contraofensiva ditatorial, cujo objetivo era atingir a espinha dorsal do novo sindicalismo, num primeiro momento através de medidas persuasivas e, posteriormente, através de violenta repressão. Foi exatamente nesta contextualização política que foi implementada a "nova política salarial” de novembro de 1979, que objetivava 
principalmente conter e mesmo fazer refluir o movimento reivindicatório grevista ${ }^{12}$

Como já esperado, as contrapropostas viriam bem abaixo do solicitado: 3,65\% de aumento acima do INPC, o piso salarial oferecido era a metade do demandado e as outras reivindicações, referentes à estabilidade, à redução de jornada, aos delegados sindicais e aos controles das chefias, foram todas negadas. Com os prenúncios do movimento grevista, o índice de aumento ainda foi irrisoriamente elevado para $5 \%$.

No dia 30 de março, em assembleia, os metalúrgicos do ABC decidem paralisar suas atividades a partir do dia seguinte, $1^{\circ}$ de abril de 1980. Já nesse dia, em São Bernardo, a greve contava com a adesão de $90 \%$ da categoria. Nesse mesmo primeiro dia, o TRT julgou-se incapaz de decidir sobre a legalidade ou não da greve e elaborou uma proposta alternativa, que não contemplava o interesse dos(as) trabalhadores(as) em greve. Apresentada essa proposta, ela cumpriu em parte com seus desígnios, já que alguns sindicatos do interior aceitam o estabelecido e acabam com a sua participação na greve. Quanto aos metalúrgicos do ABC, ainda que reconhecendo certa vitória, não aceitaram os termos estabelecidos e continuaram seu movimento ainda com $90 \%$ de adesão à greve.

Apesar da saída dos metalúrgicos de Santo André e de São Caetano no oitavo dia de greve, a empresa Termodinâmica, cedendo à negociação, dava indícios de que o desfecho poderia estar próximo. Mas não estava. Um

\footnotetext{
12 Essa nova política propunha a semestralidade nos aumentos salariais, aumentos com índices pouco acima do INPC para as faixas inferiores na escala salarial e regime diferenciado de aumentos. Além disso, a referida política estabelecia condições para a negociação direta para a obtenção de aumento anual. Para tanto, o aumento só poderia ser negociado com base no crescimento da produtividade da empresa. Obviamente, como assinalou Antunes (1988, p. 65), opera-se "uma epidérmica e superficialíssima modificação na política salarial, sem jamais eliminar o arrocho salarial”.
} 
segundo julgamento do TRT invalidou a primeira decisão e decretou a ilegalidade da greve. Assim, tudo o que o regime e o capital queriam foi conseguido. Com a ilegalidade da greve decretada, já havia respaldo legal para as ações repressivas que se sucederam, caindo pesadamente sobre os(as) trabalhadores(as), seus líderes e suas entidades.

No dia 17 de abril de 1980, o governo intervém nos sindicatos de São Bernardo do Campo e de Santo André. O ministro do Trabalho, Murilo Macedo, adicionava mais intervenções à sua lista. Dessa vez, não se conteve apenas com a intervenção e a cassação das lideranças do movimento. Os líderes grevistas e outras personalidades representantes de associações liberais foram presos. Os metalúrgicos haviam se preparado bastante, em termos de estruturação, em caso da quase certa intervenção. Com os primeiros ataques do governo, as estruturas de apoio desenvolvidas começam a desempenhar seus papéis.

O governo e os empresários jogavam uma cartada alta à medida que um sucesso desse movimento traria um incremento do movimento sindical, já sentido a partir de 1978 e 1979. Assim, era preciso demonstrar quem tinha as cartas e quem controlava o jogo. Os metalúrgicos, sem seu sindicato - como haviam programado -, reúnem-se no Estádio de Vila Euclides e no Paço Municipal, em São Bernardo, e no Estádio da Vila Jaçatuba, em Santo André, e, com as proibições de assembleias pelo governo, na Igreja Matriz e nos bairros.

Interessante perceber a dinâmica da verdadeira luta espacial que se travou com a ditadura e com os patrões, que tentavam limitar ao máximo todos os espaços possíveis de organização e mobilização, e os(as) trabalhadores(as), que iam abrindo e encontrando espaços alternativos para sua ação. Na terceira semana de greve, os metalúrgicos tentam manter o ímpeto do movimento. A essa altura, já haviam adicionado às reivindicações anteriores a exigência da 
libertação dos presos e o fim da intervenção nos órgãos de classe.

O quadro estava montado. O governo endurecia enxugando os espaços possíveis de reunião, sobrando apenas os espaços internos da Igreja. Os empresários, por seu turno, reforçavam as práticas repressivas e de persuasão como de costume. Os(as) trabalhadores(as) tentam o quanto podem seguir com o movimento. Os confrontos entre operários e as tropas policiais não eram raros dentro do cenário. Já se podia perceber esparsamente um movimento de retorno ao trabalho. Ainda assim, o $1^{\underline{0}}$ de maio de 1980, que reuniu mais de 100 mil metalúrgicos, retomando o Estádio de Vila Euclides, dava novos ânimos ao movimento.

Mas o refluxo do movimento começava mesmo a ser sentido. Logo no início de maio, os metalúrgicos de Santo André decidem voltar ao trabalho e encerrar o movimento. Já apresentando sinal de desgaste, os metalúrgicos do ABC põem fim ao seu movimento grevista que durou 41 dias. Lula e outras lideranças permaneceriam presos por mais alguns dias quando um recurso apresentado pelo advogado do Comitê Brasileiro pela Anistia (CBA) consegue o relaxamento da prisão preventiva. Os sindicalistas serão processados com base na Lei de Segurança Nacional (LSN), em julgamento por tribunal militar que se realizará no início de 1981.

A greve dos metalúrgicos do ABC em 1980 apresentou de forma clara não só as disposições de governo e empresários, mas, sobretudo, as limitações e restrições a que se submetia o movimento operário e sindical brasileiro. Na análise de suas lideranças, o movimento acabou enfrentando problemas internos e externos. Como disse Lula,

Nós acreditávamos que sozinhos venceríamos a classe empresarial do $\mathrm{ABC}[. .$.$] . O que não contávamos era que$ o Estado jogasse tão pesado como jogou em defesa das 
empresas, coisa que não fez em 79... A gente tinha esperança de que o governo não iria bancar tudo sozinho. Mas ele bancou tudo do começo ao fim, desde o Tribunal até os helicópteros do Exército (Escrita Ensaio, n. 9, 1980, p. 27).

Para José Cicote, uma outra liderança, em depoimento ao Correio Sindical, no 18, de dezembro de 1980, a perspectiva de ter saído da greve quando da determinação do índice pelo TRT poderia ter sido a mais acertada. Segundo ele (Santana, 2001, p. 210),

Quando houve aquele julgamento do TRT [...] eu fiquei em dúvida sobre qual a posição correta a tomar. Hoje eu acho que aquele pronunciamento do TRT foi uma vitória que poderia beneficiar todos os trabalhadores brasileiros. Se tivéssemos voltado ao trabalho no outro dia, ampliaríamos a vitória para todo o país. Isso porque, no resto do país, ninguém mais poderia declarar ilegal uma greve daquelas. Mas nós não vimos as outras categorias e isso foi um erro da gente.

Além disso, a greve de 1980, aprofundando um processo já presente nas de 1978 e 1979, abriu, ainda mais, a clara distinção na lógica de ação dos diversos grupos que militavam no movimento operário e sindical brasileiro. Essa distinção informará a orientação, atuação e relação desses grupos, constituindo uma dinâmica ao longo de toda a década de 1980.

No que tange à greve de 1980, pelo menos em termos de seus quadros dirigentes e publicações (por exemplo, Voz da Unidade de 22 a 28 de maio de 1980), o PCB desenvolveria a seguinte linha de análise: eles vão dar apoio à greve, mesmo avaliando que, após a definição do índice pelo TRT, teria sido mais efetivo sair da greve, à medida que a continuidade do movimento escaparia do espectro meramente sindical e passaria a ser, como foi, uma queda de braço com o governo e os patrões. Para tanto, segundo eles, seria necessário uma 
preparação que envolvesse não só os metalúrgicos, mas também outros setores da oposição que servissem de apoio ao movimento ${ }^{13}$. Para um enfrentamento mais imediato com o regime, era necessário mais que um esforço de estruturação e organização interna.

$\mathrm{O}$ isolamento e a radicalidade do movimento teriam sido os responsáveis por tê-lo colocado em um beco, com margem pequena de manobra. Interessados na proposição da frente política pela democratização, os comunistas não só jogavam peso na construção dessa frente, como também, buscavam evitar embates que não levassem em conta a "correlação de forças no interior da sociedade". Todo movimento poderia ser transformado em um ato contra o regime, contanto que fosse eficaz. Em caso de derrota, e eles deixaram isso claro, poderia levar também a uma derrota dos setores democráticos como um todo.

Tendo esse tipo de leitura em primeiro plano, baseando-se sempre nas linhas de orientações gerais do partido, os comunistas acabaram por afastar-se do que, naquele momento, seria o polo mais dinâmico do movimento sindical e que, tornando-se hegemônico, capitanearia as formas de organização e luta da classe trabalhadora na década que se iniciava.

Pode-se dizer que, a partir de 1978, temos um dos marcos importantes do início de um processo de rearranjo entre as forças atuantes no movimento sindical. No V Congresso da Confederação Nacional dos Trabalhadores na Indústria (CNTI), um grupo de sindicalistas que incluía desde os novos atores até os militantes do PCB se diferia dos pelegos na medida em que propunha uma ação mais combativa para os sindicatos (Rodrigues, 1991). Esses sindicalistas seriam chamados de autênticos. Porém, com o caminhar do processo, nesse mesmo bloco, algumas distinções de posição se

13 De certa forma, ainda que partindo de posições diametralmente opostas, algumas das posições expostas pelos comunistas em seus periódicos acerca da greve do ABC de 1980 estavam presentes nas falas de Lula e de Cicote citados anteriormente. 
estabeleceriam. Em 1979, nos diversos encontros sindicais, vão ficando claras as divergências sobre, entre outras coisas, a postura desses sindicalistas acerca da estrutura sindical e a forma de enfrentá-la.

Em congressos como o dos metalúrgicos em Poços de Caldas/MG, iam ficando evidentes as divisões. Daí a consolidação de outro bloco, autodenominado Unidade Sindical, que agregava, além de alguns sindicalistas que estiveram próximos dos autênticos, setores mais conservadores do movimento. Nesse bloco, também se integravam militantes de outros agrupamentos de esquerda como o Partido Comunista do Brasil (PCdoB) e do Movimento Revolucionário 8 de Outubro (MR8). Assim, os blocos se consolidavam. De um lado, a Unidade Sindical, que incluía nomes como Arnaldo Gonçalves e Joaquim dos Santos Andrade; de outro, os chamados autênticos, tendo à frente nomes como Lula, Olívio Dutra e Jacó Bittar.

Além, desses dois blocos, um terceiro grupo se apresentava correndo em via paralela. Eram as Oposições Sindicais, que agrupavam militantes de esquerda, egressos ou não da experiência da luta armada, e/ou militantes ligados à Igreja, setor que apresentava uma plataforma que tinha como centro o combate à estrutura sindical corporativa a partir de um intenso trabalho de base via comissões de fábrica. Sua maior expressão estava na Oposição Sindical Metalúrgica de São Paulo e podia apresentar posições que iam desde a aceitação do trabalho conjunto com o "sindicato oficial", como pregava José Ibrahim, até setores contrários a esse tipo de articulação. Rodrigues (1991) assinala ainda a existência de um outro bloco relacionado aos grupos de extrema esquerda e ao sindicalismo revolucionário.

É em um quadro de redefinições como esse que teremos posições diferentes acerca da greve dos metalúrgicos. As divergências da Unidade Sindical com a diretoria do 
Sindicato dos Metalúrgicos do ABC podem ser sentidas ao longo de todo o movimento.

A posição daquele grupo em termos da solidariedade à greve fica expressa, por exemplo, no jornal Correio Sindical (no 9-10) (Antunes, 1988). Acerca da campanha salarial em curso, o jornal assinala que

Devemos compreender que esta campanha salarial que se desenvolve não é só do ABC. Mas sim de todos os metalúrgicos do interior e que cabe aos nossos sindicatos a tarefa de defender a unidade com a Federação, marcando posição firme e que desmascare as diretorias divisionistas e vacilantes de outros sindicatos. É participando e defendendo posições unitárias que caminharemos rumo à conquista da direção da Federação. (Antunes, 1988, p. 76)

O que se vê é uma crítica às direções divisionistas e o lembrete de que a campanha não era só do ABC. Vale assinalar que nesse ano, como nos anteriores, os metalúrgicos do ABC, seguidos por outros sindicatos do interior, definiram-se por uma campanha autônoma àquela gerenciada pela Federação dos Metalúrgicos de São Paulo. Na análise do PCB, só a unidade garantiria o avanço da luta e abriria o caminho para a conquista da direção da federação. Diferentemente da visão do PCB, era evidente que os metalúrgicos do $\mathrm{ABC}$ não estavam muito interessados, pelo menos naquele momento, em disputar a direção da federação com os setores pelegos.

Outro exemplo de divergência se deu nas diferentes posturas com relação ao apoio à greve. A Unidade Sindical resolveu elaborar um bônus próprio com o qual recolheria recursos a serem doados a São Bernardo, em uma das muitas campanhas de solidariedade que atravessaram o país na época. Dessa forma, vendia outros bônus que não os administrados pela organização do movimento. Isso gerou sérias 
críticas e mesmo suspeitas. Em entrevista ao jornal Em Tempo, $n^{\circ} 107$, de junho de 1980, Lula, perguntado como analisaria a atuação da Unidade Sindical ao longo da greve, afirma: "Segundo informações que tenho [...], eu acho que o setor que menos ajudou a gente foi o setor da Unidade Sindical. Os que mais ajudaram foram aqueles que racharam, que agiram paralelamente à Unidade Sindical” (Silva, 1981, p. 296) .

A greve de 1980 fecha essa primeira parte do longo ciclo de greves que vai de 1978 a 1997 (Noronha, 2009). Ela apresenta trabalhadores(as), patrões e Estado, em termos daquela conjuntura, em um grau avançado no que tange à sua preparação para o confronto político. A partir daí, na entrada da nova década, os(as) trabalhadores(as), ainda que mantendo o ímpeto reivindicativo, buscam formas alternativas de empreender seus movimentos lançando mão de formas bastante criativas. O período de recessão econômica que se abre e se arrastaria nesse momento também produ52 zirá seus efeitos nos meios operários e sindicais, bem como nas formas de mobilização da classe trabalhadora.

Nesse período, haverá a fundação do PT, em 1980; e da CUT, em 1983. Ambos servirão, tendo em muito como base a experiência desse início de ciclo, tornando-se hegemônicos em suas áreas de atuação, de importantes instrumentos no processo de canalização da conflitividade social na década de 1980. Essa década se tornaria uma década sindical por excelência, tornando-se um dos período de ouro da história do movimento operário e sindical no país. Será por isso que, para o capital, ela era entendida no surrado mantra da "década perdida". Como disse Lula durante a greve de 1980, "Que ninguém jamais ouse duvidar da capacidade de luta da classe trabalhadora" (French, 2010, p. 286).

\section{Considerações finais}

Observados os três movimentos grevistas que estiveram na base de um longo ciclo de contestação alguns pontos 
importantes ficam bastante salientes. Eles tem contornos claros do que Tilly e Tarrow caracterizam como confronto político. Segundo eles,

Confronto político envolve interações nas quais atores fazem demandas dirigidas aos interesses de outros atores, levando a esforços coordenados em nome de interesse compartilhados ou programas, e nas quais governos são envolvidos como alvos, iniciadores de demandas ou terceiras partes. Confronto político, portanto, associa três elementos familiares da vida social: confronto, ação coletiva e política. (Tilly; Tarrow, 2015, p. 7)

Os três movimentos, em anos consecutivos, servem para identificarmos, no surgimento de um ciclo de contestação mais longo, elementos em termos de orientação, organização e mobilização que, no todo ou em parte, estarão presentes durante todo o ciclo. Alguns desses elementos, lançados nesse momento, configuram-se em performances diferentes de anteriores até então utilizadas e produzem impactos no que diz respeito ao repertório de ação coletiva. Esses elementos, posteriormente, serão repetidos e/ou alterados. Ao mesmo tempo, esse período reproduz e reitera outros tantos aspectos das formas de orientação, organização e mobilização já presentes historicamente no acervo vivo de lutas da classe trabalhadora brasileira.

Diante do quadro que experimentavam as forças em jogo, os repertórios de ação coletiva, até ali em vigência, precisavam ser colocados em tela, criticados, ressignificados, repensados, reiterados e/ou atualizados em suas táticas. Segundo McAdam, Tarrow e Tilly (2009):

as ações dos movimentos sociais assumem a forma de repertórios: números limitados de desempenhos alternativos historicamente estabelecidos ligando reivindicadores a objetos de reivindicação [...]. Os repertórios não são 
simplesmente uma propriedade dos atores do movimento; são uma expressão da interação histórica e atual entre eles e seus opositores. (McAdam; Tarrow; Tilly, 2009. p. 24)

Nesse sentido, na historicidade dos repertórios, passado e presente se articulam. Um opera sobre o outro. Mais do que uma anulação de um pelo outro, há aí uma tensão entre ruptura e continuidade, entre reforma e permanência, entre inovação e persistência. Segundo McAdam, Tarrow e Tilly (2009, p. 29),

Os repertórios existentes corporificam uma tensão criativa entre inovação e persistência, refletindo suas lógicas instrumental e expressiva muito diferentes. A eficácia instrumental de um repertório deriva basicamente de sua novidade, de sua habilidade [...]. O uso repetido do mesmo repertório diminui sua eficácia instrumental e, desta forma, encoraja a inovação tática.

Em termos de sua dinâmica de confrontação, trabalhadores(as), patrões e Estado lançaram mão de arsenal variado de práticas no sentido de diminuir as margens de manobra de seus adversários. Como reivindicadores, trabalhadores(as) e suas organizações, dentro e fora das fábricas, buscaram tensionar o quadro estabelecido e limitante para a consecução de seus objetivos, buscando alterá-lo. Já patrões e Estado empreenderam suas energias no sentido da manutenção do estado de coisas vigente, tanto em termos do mundo do trabalho como em termos políticos mais gerais.

A dinâmica do jogo da confrontação, como sempre, produziu resultados positivos e negativos, "vitórias" e "derrotas", de curto, médio e longo prazo, para todos os envolvidos. A derrota em termos de índices econômicos, não significava necessariamente uma derrota política e/ou organizativa. A presença da força repressiva nem sempre, ainda que tenha 
acontecido em alguns momentos, serviu para arrefecer os ânimos dos movimentos. Assim, tal presença significou fechamento do horizonte de ação e possibilidades, mas também a abertura de outros. Essa dinâmica exigiu mudanças constantes por parte dos atores em confronto. As táticas utilizadas durante as três greves, em qualidade e/ou quantidade, foram diferentes entre si, como diferentes em cada momento dos movimentos específicos, apesar da manutenção de certos eixos assemelhados de ação e organização.

Olhando o movimento dos(as) trabalhadores(as), pode-se perceber todo o processo de construção de identidades e de atores coletivos ao longo da dinâmica de confrontação. Mais do que atores fixos e estáticos, eles vão se constituindo no desenrolar da confrontação. Foram se constituindo como agentes e produzindo estruturas que alicerçassem essa constituição e sua permanência, "estruturas de mobilização" e "enquadramento de ação" (Tarrow, 2009). As orientações e práticas do chamado "novo sindicalismo" (Santana, 1999) servirão como identidade e base de sustentação e organização para estes "novos atores" que emergem neste contexto.

Como já sinalizei em outro momento, é possível afirmar que o chamado "novo sindicalismo" representou a reedição de práticas já experimentadas na história do sindicalismo por setores que, ao seu tempo, se identificavam com posições progressistas em relação à luta dos(as) trabalhadores(as). Dessa forma, ele pode ser visto como inserido em uma longa tradição no movimento sindical brasileiro. Identificando-se com o polo mais dinâmico da classe trabalhadora, o "novo sindicalismo" forneceu-lhe importante contribuição no sentido de combater as políticas conservadoras e restritivas para os(as) trabalhadores(as) e o movimento sindical.

Ocupando um lugar que outras forças haviam ocupado no passado, o "novo sindicalismo" garantiu à classe trabalhadora um canal fundamental de representação e de 
encaminhamento de suas demandas. Como bem assinalou Sader (1988, p. 182):

A particularidade que marcou a corrente dos "autênticos" foi sua capacidade de absorver as pressões das bases e canalizá-las para o interior do aparelho sindical. Tratou-se de uma operação das mais delicadas. Era tão estreita a margem legal para seu trabalho que viviam na ambiguidade entre querer evitar a insatisfação das bases e tentar manter o respeito à legalidade.

Nesse sentido, sempre, claro, com idas e vindas, limites e possibilidades, são dignas de nota as maneiras pelas quais esse movimento articulou formas verticais e horizontais de organização e mobilização, bem como empreendeu formas decisórias que conjugavam democracia representativa e democracia participatória. A presença e a articulação orgânica de diferentes movimentos nesse ciclo - bairros, religiosos, contra a carestia, mulheres etc. -, garantiram-lhe, não sem tensão, grande complexidade, riqueza, profundidade e extensão.

O "novo sindicalismo", fruto e motor dileto deste processo, representou um grande força de redemocratização da vida sindical brasileira, tendo suas ações repercutido no sentido de auxiliar na redemocratização da sociedade brasileira (Rodrigues, 1997). Porém, também como experiências do passado, o "novo sindicalismo", que se tornou o projeto sindical mais forte e mais duradouro da história da classe trabalhadora brasileira, enfrentou, ao longo de todo o seu desenvolvimento, dificuldades cuja resolução continua sendo um desafio para a classe trabalhadora brasileira.

Se o "novo sindicalismo" representa essas dimensões para o campo sindical, o PT representará para o campo político. O PT será outro fruto e motor dileto desse processo. Interessante perceber como um movimento que se queria 
"apolítico", "apartidário" e distante da "ação política", politiza-se rapidamente, e até se partidariza, produzindo atores e instituições políticas de grande pujança, efetividade e impacto na ação política.

As articulações orgânicas entre o PT e os movimentos popular e sindical deram a esse partido características próprias. Além disso, sua vida interna, complexa e rica viveu vários momentos de criativos experimentos democráticos. Contudo, como nas experiências de partido desse corte, o PT caminhou para um processo de institucionalização e burocratização que, ainda que se aleguem necessários para as demandas do sistema político e eleitoral, e que, sem dúvida, o levaram à hegemonia da esquerda brasileira, à sentida força parlamentar e à presidência da República, significaram também o progressivo distanciamento de suas bases populares, da democracia interna e da relação mais orgânica com os movimentos sociais. O partido, pode-se dizer, viveu à sua própria maneira, pelos caminhos que sua maioria interna escolheu, a tragédia dos partidos social-democratas europeus.

Pensando a partir de pontos específicos de ontem e de hoje, algumas questões se estabelecem. Vivemos, apesar da manutenção de sua essência, em momentos de capitalismo muito diferentes, com correlata formação de classe distintas. O mesmo aconteceu em termos de regime político. Essas são mudanças substanciais para o entendimento de qualquer tentativa de aproximação entre as dinâmicas de confrontação e a ação coletiva.

Considerado em termos gerais, o "novo sindicalismo" representava e operava no sentido da constituição de um ator coletivo. Ele foi produto e produtor da articulação de demandas e da produção de novas vertebrações de sentido, que resultaram em um processo de construção de identidade. Ao interpelar os(as) trabalhadores(as) como classe trabalhadora, produzia-se uma ampliação do sentido da 
composição do mundo do trabalho. Além disso, buscava-se distanciar da ideia política de classe operária vinculada a um conjunto de organizações então já longevas na militância política e sindical. Assim, como classe operária em momentos anteriores, classe trabalhadora, para além de sua dimensão descritiva, tinha um claro efeito político, portando elementos de demandas, orientação, organização, mobilização e conflito.

Nos dias de capitalismo neoliberal, claramente apresentados como uma contraofensiva sobre as conquistas e os avanços históricos do movimento da classe trabalhadora, vários processos foram postos em marcha exatamente no sentido de minar, limitar e reduzir quaisquer possibilidades, em termos da luta de classes, de um ascenso organizativo e mobilizatório dos(as) trabalhadores(as). Ao mesmo tempo em que acelera a lógica da vida - no vertiginoso "parou, perdeu" -, ataca todas as formas de segurança e seguridade, dentro e fora do mundo do trabalho. Formas de proteção são extintas, desprotegendo a vida no trabalho, bem como o enxugamento das formas de proteção após a vida no trabalho com ataques, chamados "reformas", aos sistemas previdenciários. O que, conjugado aos índices astronômicos globais de trabalho precário e desemprego, fornece contornos ainda mais deletérios ao quadro social.

No processo de contraofensiva, as tentativas históricas do capital de individualizar e fragmentar a identidade coletiva de classe dos(as) trabalhadores(as) ganham nova força. Buscando eliminar a conflitividade dos horizontes sociais, o capital implantou com eficiência a substituição de termos com histórica conotação de conflito, como classe operária, operários(as), trabalhadores(as), por outros vinculados a outro campo semântico. Assim, entraram em cena termos como colaboradores(as), cliente interno, fornecedor interno etc. Os primeiros praticamente desapareceram do dicionário e do vocabulário corrente no mundo do trabalho. 
A ideia de colaborador(a) - aquele (a) que "co"-"labora", trabalha junto, não conflita - dá bem a ideia das expectativas e estratégias do capital nesse sentido.

A noção de que a fragmentação da classe, que seria uma de suas características hoje, tornaria sua organização e mobilização processos muito difíceis, senão impossíveis; e dada a tendência à desagregação e à divisão feririam de morte as formas solidárias, como o sindicalismo, teve uma rotunda resposta, entre outros, de Hyman (1996). Ele demonstra, buscando escapar de certa idealização frequente, como a fragmentação tem sido uma constante no mundo do trabalho, assim como tem sido a tentativa de sua superação através de formas de solidariedade. Dificuldade e impossibilidade não são sinônimos. A classe sempre foi um projeto, que tem uma forte dimensão política. É preciso formá-la. O que o capital tem feito, com mais ou menos sucesso em diferentes momentos, é desconstruí-la em um sentido e construí-la em outro.

Em sua crítica à tese da desagregação Hyman (1996) argumenta que o que estaria em jogo seria uma visão mitificada do passado percebido como uma época dourada em que os(as) trabalhadores(as) eram espontaneamente coletivistas e as organizações laborais alinhavam-se por detrás de um projeto de classe unificador.

Essa linha de raciocínio amplia a margem do debate sobre a "crise", confere importância às transformações particulares e relativiza afirmações sobre a existência de uma tendência do coletivismo ao individualismo por ser uma interpretação unilateral de um conjunto de processos culturais complexos e variados. Para essa perspectiva, embora os ideólogos dos sindicatos possam ter concebido tradicionalmente o coletivismo como um valor moral em si, o mais realista seria supor que - à parte os momentos de mobilização de massas - a maioria dos membros dos sindicatos aderiu à organização coletiva como meio mais eficaz de tornar realidade suas necessidades e aspirações individuais. 
A partir desse ponto de vista, mais do que uma crise dessas formas de organização, estaríamos diante de uma crise do estilo e das orientação tradicionais do sindicalismo. Nesse sentido, deve-se fazer uma análise fina da questão da solidariedade e perceber que os princípios e as práticas do sindicalismo sempre mostraram uma tensão entre ambiciosas declarações de solidariedade, em geral, vinculadas às metas da transformação socialista, e as rotinas de defesa dos interesses imediatos do emprego de categorias específicas de afiliados.

Buscando desmistificar interpretações que apontam para uma situação mais catastrófica, pode-se argumentar que a noção de classe operária sempre foi uma abstração, nunca uma descrição ou generalização sociológica e que a diferenciação, a divisão e a desunião têm sido traços onipresentes do desenvolvimento sindical. Porém, apesar das circunstâncias adversas, segue existindo um espaço para as iniciativas estratégicas dos movimentos trabalhistas, de maneira que seja possível contar com novos meios para transcender as divisões e construir o interesse comum. O que imporia uma nova lógica, um novo vocabulário de motivos para a solidariedade dos(as) trabalhadores(as).

Trabalhadores(as) e suas organizações, durante o ciclo de contestação das greves de 1978-1980, produziram seu próprio caminho lançando mão de repertórios existentes, mas gerando tensão criativa ao apresentarem suas inovações diante do quadro particular que experimentavam. Interessante notar como as greves tiveram elementos diferentes entre si, assim como, para manter sua eficácia, precisaram ser diferentes ao longo de toda a década de 1980.

Apesar de todas as tentativas de se obscurecer esse fato, vale lembrar, como quadro geral, que vivemos em uma sociedade capitalista, estruturada em classes sociais, que travam a luta de classes. Os desafios que estão postos hoje para uma nova classe trabalhadora - novo proletariado, novo precariado etc. - têm sido, logo de início, vencer as desconfianças políticas que a cercam, pois já caiu sobre ela um conjunto de, 
digamos, prenoções (por exemplo, Standing, 2013) pouco ou nada lisonjeiras. Ao mesmo tempo, ainda que traga inovações importantes e necessárias, não pode simplesmente abolir a história de organização e luta de gerações e gerações.

Na mesma direção, precisa produzir seus próprios instrumentos de luta atualizados, que canalizem suas demandas e sua conflitividade, sem com isso também precisar negar e/ ou abolir as ainda vivas possibilidades de formas organizativas que foram legadas pelas gerações anteriores. Essa tem sido uma caraterística histórica importante na trajetória de trabalhadores(as) na articulação de formas novas com as pretéritas, por dentro e por fora das organizações sindicais. A luta e a organização da classe trabalhadora sempre se ajustaram aos momentos históricos em que atuavam.

Nesse sentido, hoje, as orientações, demandas e formas de luta centrais no projeto de constituição dessa classe, não podem prescindir da interseccionalidade entre, por exemplo, classe, raça, etnia e gênero; da conjugação de formas de organização e mobilização horizontais e verticais; e de formas decisórias organizadas em torno de democracia baseada na representação, mas também, e sobretudo, na participação. Não há como pensar esse processo ancorado apenas em um tipo de organização, sejam partidos, movimentos, sindicatos; antes, pensá-lo a partir de uma multiplicidade articulada de plataformas. Múltiplas são as formas de exploração e opressão das quais o capitalismo lança mão, assim como múltiplas e diversas têm sido, e precisam ser, as respostas coletivas a elas. $\mathrm{O}$ ciclo de contestação de 1978-1980 contém lições indispensáveis nesse sentido.

\section{Marco Aurélio Santana}

É professor do Programa de Pós-Graduação em Sociologia e Antropologia e do Departamento de Sociologia do Instituto 
de Filosofia e Ciências Sociais da Universidade Federal do Rio de Janeiro (IFCS-UFRJ). Rio de Janeiro, Rio de Janeiro, Brasil.

\section{Bibliografia}

AARÃO REIS FILHO, Daniel; RIDENTI, Marcelo; MOTTA, Rodrigo Patto Sá (orgs.). 2004. O golpe e a ditadura militar: 40 anos depois, 1964-2004. Bauru: Edusc.

ABRAMO, Laís. 1999. O resgate da dignidade: greve metalúrgica e subjetividade operária. Campinas: Editora da Unicamp.

ANGELO, Vitor Amorim de; VILLA, Marco Antônio (orgs.). 2009. O Partido dos Trabalhadores e a politica brasileira (1980-2006). São Carlos: EdUFSCar.

ANTUNES, Ricardo. 1988. A rebeldia do trabalho. Campinas: Editora da Unicamp; Ensaio.

ANTUNES, Ricardo; SANTANA, Marco. 2014. The dilemmas of the new unionism in Brazil - breaks and continuities. Latin American Perspectives, v. 41, n. 5, pp. 10-21.

BERBEL, Márcia Regina. 1991. 147 f. Partido dos Trabalhadores: tradição e ruptura na esquerda brasileira, 1978-1980. Dissertação de Mestrado em História Econômica. São Paulo: USP.

BOITO JR., Armando (org.). 1991. O sindicalismo brasileiro nos anos 80. Rio de Janeiro: Paz e Terra.

CADERNOS DO PRESENTE. 1968. Greves Operárias (1968-1978).

Cadernos do Presente, n. 2, São Paulo: Aparte.

CAMPANHAS salariais. 1980. ABC de luta! Memória dos Metalúrgicos do ABC. Disponível em: <https://bit.ly/2ubURLg>. Acesso em: 11 jul. 2018.

CARONE, Edgard. 1982. O PCB - 1964/1982. Vol. 3. São Paulo: Difel.

CRIAÇÃO do Fundo de Greve em São Bernardo do Campo. 1979. ABC de luta! Memória dos Metalúrgicos do ABC. Disponível em: <https:/ /bit. ly/2KR6TUR >. Acesso em: 11 jul. 2018.

ESCRITA ENSAIO. 1980. SÃO PAULO: Escrita, n. 9.

FERREIRA, Marieta de Moraes; FORTES, Alexandre (orgs.). 2008. Muitos caminhos, uma estrela: memórias de militantes do PT. São Paulo: Editora Fundação Perseu Abramo.

FICO, Carlos; ARAUJO, Maria Paula Nascimento (orgs.). 2009. 1968 - 40 anos depois: história e memória. Rio de Janeiro: 7Letras.

FREDERICO, Celso. 1987. A esquerda e o movimento operário 1964/1984. Vol. 1. São Paulo: Novos Rumos.

FRENCH, John D. 2010. Resenha: Antonio Luigi Negro, Linhas de montagem: o industrialismo nacional-desenvolvimentista e a sindicalização dos trabalhadores. Tempo Social, vol.22, no.1, pp. 277-287. 
GADOTTI, Moacir; PEREIRA, Otaviano. 1989. Pra que PT: origem, projeto e consolidação do Partido dos Trabalhadores. São Paulo: Editora Cortez.

GORENDER, Jacob. 1987. Combate nas trevas. São Paulo: Ática.

GREVE geral dos metalúrgicos do ABC. 1979. ABC de luta! Memória dos Metalúrgicos do ABC. Disponível em: <https://bit.ly/2zvrs3Q >. Acesso em: 11 jul. 2018.

HUMPHREY, John. 1980. As raízes e os desafios do "novo" sindicalismo da indústria automobilística. Estudos Cebrap, n. 26, pp. 5-39. 1982. Fazendo o milagre. Petrópolis: Vozes; Cebrap.

HYMAN, Richard. 1996. Los sindicatos y la desarticulación de la clase obrera. Revista Latinoamericana de Estudios del Trabajo, v. 2, n. 4, pp. 9-28.

KECK, Margaret. 1991. PT, a lógica da diferença. São Paulo: Ática.

KRISCHKE, Paulo José (org.). 1982. Brasil: do "milagre” à “abertura”. São Paulo: Cortez.

MARANHÃO, Ricardo. 1981. Os trabalhadores e os partidos. São Paulo: Semente.

MARONI, Amnéris. 1982. A estratégia da recusa: análise das greves de maio/78. São Paulo: Brasiliense.

MARTINS, Heloisa de Souza. 1994. Igreja e movimento operário no ABC. São Paulo: Hucitec.

MATTOS, Marcelo Badaró. 2002. Trabalhadores e sindicatos no Brasil. Rio de Janeiro: Vício de Leitura.

McADAM, Doug; TARROW, Sidney; TILLY, Charles. 2004. Dynamics of contention. Cambridge: Cambridge University Press. 2009. Para mapear o confronto político. Revista Lua Nova, n. 76, pp. 11-48.

MENEGUELLO, Rachel. 1989. PT: a formação de um partido. Rio de Janeiro: Paz e Terra.

MOISÉS, José Álvaro. 1982. Lições de liberdade e de opressão: o novo sindicalismo e a política. Rio de Janeiro: Paz e Terra.

MUNAKATA, Kazumi. 1980. O lugar do movimento operário. In: IV Encontro Regional de História de São Paulo, Araraquara. Anais... Araraquara: ANPUH-Unesp. pp. 61-81.

NEVES, Magda de Almeida. 1995. Trabalho e cidadania: as trabalhadoras de Contagem. Petrópolis: Vozes.

NORONHA, Eduardo. 1991. A explosão das greves na década de 80. In: BOITO JR., Armando (org.). O sindicalismo brasileiro nos anos 80. Rio de Janeiro: Paz e Terra, 1991. pp. 93-135. 2009. Ciclo de greves, transição política e estabilização: Brasil, 1978-2007. Lua Nova, n. 76, pp. 119-168. 
OLIVEIRA, Isabel Ribeiro de. 1988. Trabalho e política - O Partido dos Trabalhadores. Petrópolis: Vozes.

PARANHOS, Kátia. 1999. Era uma vez em São Bernardo: o discurso sindical dos metalúrgicos - 1971/1982. Campinas: Editora da Unicamp.

PCB - Partido Comunista Brasileiro. 1980. Vinte Anos de Política -

Documentos (1958/1979). São Paulo: Ciências Humanas.

POLLETTA, Francesca. 2006. It was like a fever: storytelling in protest and politics. Chicago: University of Chicago Press.

RAINHO, Luis Flávio. 1980. Os peões do grande ABC. Petrópolis: Vozes.

RODRIGUES, Iram Jácome. 1997. Sindicalismo e política: a trajetória da CUT. São Paulo: Scritta; Fapesp.

RODRIGUES, Leôncio Martins. 1991. As tendências políticas na formação das centrais sindicais. In: BOITO JR., Armando (org.). O sindicalismo brasileiro nos anos 80. Rio de Janeiro: Paz e Terra, 1991. pp. 11-42.

SADER, Eder. 1988. Quando novos personagens entraram em cena. Rio de Janeiro: Paz e Terra.

SADER, Emir. 1987. The Workers' Party in Brazil. New Left Review, v. 1, n. 165, pp. 93-102.

SANTANA, Marco Aurélio. 1999. Entre a ruptura e a continuidade: visões da história do movimento sindical brasileiro. Revista Brasileira de Ciências Sociais, v. 14, n. 41, pp. 12-26. 2001. Homens partidos: comunistas e sindicatos no Brasil. São Paulo: Boitempo; Rio de Janeiro: Unirio. . 2007. Esquerdas em movimento: a disputa entre PCB e PT no sindicalismo brasileiro dos anos 1970/1980. Perseu: História, Memória e Política, n. 1, pp. 37-67.

2012. Partidos e trabalhadores na transição democrática: a luta pela hegemonia na esquerda brasileira. Dados - Revista de Ciências Sociais, v. 55, n. 3, pp. 787-826.

SILVA, Luís Inácio Lula da. 1981. Lula: entrevistas e discursos. São Paulo: O Repórter.

SNOW, David; BENFORD, Robert. 1992. Master frames and cycles of protest. In: MOMS, Aldon; MUELLER, Carol. Frontiers in social movement theory. New Haven: CT Yale University Press, 1992. pp.133-155.

STANDING, Guy. 2013. O precariado: a nova classe perigosa. São Paulo: Autêntica, 2013.

TARROW, Sidney. 1993. Cycles of collective action: between moments of madness and the repertoire of contention. Social Science History, v. 17, n. 2, pp. 281-307. 2009. Poder em movimento: movimentos sociais e confronto político. Petrópolis: Vozes. 
TILLY, Charles. 1992. Réclamer Viva Voce. Cultures et Conflits, n. 5, pp. $109-126$.

. 2008. Contentious performances. New York: Cambridge University Press.

TILLY, Charles; TARROW, Sidney. 2015. Contentious politics. New York: Oxford University Press.

TOLEDO, Caio Navarro de (org.). 1997. 1964: visões críticas do golpe: democracia e reformas no populismo. Campinas: Editora da Unicamp.

VIANNA, Luiz Werneck. 1983. A classe operária e a abertura. São Paulo: Cerifa.

1986. Travessia: da abertura à constituinte 86. Taurus: Rio de Janeiro.

WEFFORT, Francisco. 1972. Participação e conflito industrial: Contagem e Osasco, 1968. São Paulo: Cebrap. 


\section{CLASSE TRABALHADORA, CONFRONTO POLÍTICO E DEMOCRACIA: $O$ CICLO DE GREVES DO ABC PAULISTA E OS DESAFIOS DO SINDICALISMO ATUAL}

MARCO AURÉLIO SANTANA

Resumo: $\mathrm{O}$ artigo analisa os movimentos de greve dos metalúrgicos do ABC Paulista, ocorridos nos anos de 1978, 1979 e 1980, marcando o início de um longo ciclo de greves e contestação que atravessará as décadas de 1980 e 1990. Nesse sentido, buscar-se-á levar em conta a dinâmica de confrontação constituída a partir das interações entre trabalhadores/as, patronato e Estado. Ainda que seja dada atenção às práticas de patrões e Estado, ênfase central será dada ao movimento da classe trabalhadora. A ideia é apresentar a forma como os trabalhadores/as participaram dessa dinâmica, percebendo os limites e possibilidades dessa participação. Isso será feito considerando fatores externos e internos ao referido movimento. Por fim, a partir das questões por ele suscitadas, colocaremos o movimento em diálogo direto com os desafios trazidos pelo momento atual do mundo do trabalho e do sindicalismo brasileiro.

Palavras-chave: Greve; Trabalhadores; ABC Paulista; Democracia; Ditadura.

\section{WORKING CLASS, POLITICAL CONFRONTATION AND DEMOCRACY: THE CYCLE OF STRIKES OF THE ABC PAULISTA AND THE CHALLENGES OF CURRENT UNIONISM}

Abstract: The article analyses the ABC Paulista metal workers' strike movements, in 1978, 1979 and 1980, which are considered to be the beginning of a long contention cycle that lasted until the 1990 s. Although taking into account the confrontation dynamics among workers, capital and state, we focus on the labor movement actions and responses, by dealing with the influence of internal and external 
factors upon the workers' movement. In the last part we put past and present in dialogue and present the issues challenging the labor collective action.

Keywords: Strike; Workers; ABC Paulista; Democracy; Dictatorship. Recebido: 15/06/2018Ａprovado: 06/07/2018 